\title{
The Otaku Culture and Its Cultural Ramifications
}

\author{
Cecilia B-Ikeguchi \\ Tsukuba Gakuin University, Tsukuba City, Japan
}

\begin{abstract}
Just like there are fanatics in sports, music and in all spheres of life, there are individuals obsessed with animation, Japanese comics, video games and the fantasy world. These people, known as the "otaku" or literally translated as "nerds" in English, are the subject of this paper. The article describes the characteristics unique to the "otaku" individuals as well as how they interact inside and outside of their "otaku" world. In the beginning, there seemed nothing wrong with the "otaku" world; it was just a social trend. But during the early 1990's, when Japan faced its first otaku serial killer, "Otaku" has become a subject of social concern in Japan. College students and young adults are strongly hit by this socio-psychological obsession with the imaginary world, causing real, not imaginary, social problems (Pustz, 1999). This paper hopes to find answers to the following questions. What is "otaku" in relation to manga and animation? What are the characteristics of the "otaku" sub-culture? What is the psychological behavior of "otaku" individuals? By tracing the spread of internet cafes, manga and anime, and otaku conventions in Asia and Europe this paper aims to trace the cultural ramifications of Japanese animation overseas.
\end{abstract}

Keywords: animation sub-culture, cultural ramification, stigmatized group

\section{Introduction}

The presence of high profile youth problems is a shared phenomenon across advanced societies with different histories, socio-economic characteristics, cultures, and traditions. Japan is no less replete with social problems involving young people when compared to other similarly advanced societies. In an analysis of the sociology of Japanese youth, Goodman, Imoto, and Toivonen (2012) provided eight detailed case studies and took the "otaku" as an example of how a youth problem category is both constructive and contested. They go on to describe the nerdy "otaku" as one of the well-known concerns in Japan alongside other issues that include first and foremost bullying, social withdrawal, and not in education, employment, or training (NEET) among others. This essay discusses the characteristics of "otaku" in a socio-historical context, covering the social stigma in its beginning - both apparent and real-until its acceptance into the mainstream of Japanese society. The paper likewise traces the local spread of the otaku culture as it relates to the youth crisis in Japan as well as its worldwide proliferation (p. 2).

If the 1970's saw concerns rise over returnees and what was known in Japanese as student apathy, and if the 1989's saw attention turn to school refusers (tokou kyuhi), the 1990's was the era of the nerdy otakus, compensated dating (enjo kosai), parasite singles and freeters....

This paper will review the literature on "otaku" culture in relation to deeper sociological issues. It explores the social background that gave birth to the otaku group and traces the social transformation of these

Cecilia B-Ikeguchi, Ph.D., Professor, Faculty of Business \& Informatics, Tsukuba Gakuin University. 
individuals. It explores how it threw the country into a youth crisis and "moral panic" (Toivonen \& Imoto, 2013, p. 68) that ultimately gave rise to a popular culture in Japan. By seeking to trace the varied meanings and practices associated with otaku culture and exploring its multifaceted nature across social and historical contexts, it shows how the otaku group developed over time, from a marginalized group to a socially acceptable sub-culture.

\section{What Is an Otaku? What Are the Characteristics of Otaku?}

The otaku culture defies a simple definition. It first emerged in Japan in the 1960's as a marginalized and stigmatized geek sub-culture, and expanded its sphere to become a major international force (Ito, Okabe, \& Tsuji, 2012). Accordingly, this section will attempt to define and describe the otaku individual and the otaku culture as one of the diverse sets of youth cultures Japan has produced in the past 30 years, and as a culture that has had a major impact globally. Various definitions and different theories have been put forth regarding the significance of "otaku" in the Japanese context, but most have been done from the socio-economic lens. This paper attempts to trace how the images evoked from sociopathic, out-of-touch from reality individuals changed to a socially accepted distinctive style of geek culture with post-modern sensibility including knowledge of pop and cyber culture and technological fluency (Ito, 2012, pp. 165-170).

As to its beginnings, Eng (2012) wrote that the term "otaku" was originally used by Japanese fans of anime and manga to refer to each other. The word "otaku" refers to the fact that otaku individuals rarely leave their homes since "otaku" literally means "your home" as well as "you" (formal language). The etymology of the term is generally used in a deprecating manner, thereby negatively stereotyping otaku as being antisocial and isolated from the world at large. This derives from one theory that says that the anime otaku persons exist and participate in large social networks within which they trade goods and information. Although they have much social contact, the otaku are not intimately associated with most of them. The social transaction in otaku networks tend to be impersonal, short-lived, and businesslike. Initially, descriptions given to otaku individuals and their group usually had negative connotations. For example, in a study of otaku college students, Eng (2012) summarized the general characteristics of otaku individuals as follows (pp. 96-102):

These individuals are general found to be shy, introvert and socially withdrawn. Common behavior such as certain social withdrawing behavior is highly correlated with other psychological disorder symptoms such as social anxiety, social phobia and inhibitions. Students with poor evaluation of them have higher tendency to be an "otaku". They are more dependent on the online world; they prefer communication via Internet, and they use online communication for almost all purposes: to see animation and movies, to download music, to access information, and many others. They prefer online shopping as well. They have reduced interpersonal and social skills which are not conducive to physical and mental health. They are more easily agitated, anxious, more introverted, more easily disturbed by emotional distress and are easily discouraged.

Azuma (2009) defined otaku individuals from the larger context of Japan's historical and economic background. According to him, otaku individuals as:

those Japanese, usually males and generally between the ages of 18 and 40 years, who fanatically consume, produce, and collect comic books (manga), animated films (anime), and other products related to these forms of popular visual culture and who participate in the production and sales of derivative fan merchandise. (p. xv)

The book claims that the otaku culture cannot be discussed nor understood without an understanding of the notion of "postmodernity" and the psychological structure of contemporary Japan. In this context, otaku has 
been defined as a general term referring to those individuals who indulge in forms of sub-culture strongly linked to anime, video games, computers, science fiction, special-effects films, anime figurines, and so on. This form of sub-culture has been described as the "otaku culture" which is often exemplified through comics and anime, maintaining an image as a youth culture. Japanese "people born between 1950 and 1960—now 30 and 40 year olds and usually holding positions in society have been described by Azuma as core consumers. Consequently, otaku culture is deeply rooted in the history of Japanese society. Just as literature and art have a history, "so too does otaku culture (albeit a brief history of forty years) and its history is certainly a reflection of transformations in Japanese society" (Toivonen \& Imoto, 2013, p. 82).

\section{A Brief Review of the History of Otaku Culture}

Azuma (2009) analyzed historically the otaku culture as having emerged as part of Japan's postmodernism which intellectual thought and culture studies frequently refer to as the culture world since the 1960s and the 1970s. In describing the origin of otaku sub-culture as dating back to the 1960s, the book asserts that there have been three generations who embrace the otaku culture that we see today (pp. 6-7).

The first generation are those who were born around 1960 and saw Battleship Yamato and Mobile Suit Gundam during their teen years. The second generation is made up of those who were born around 1970, and enjoyed the diversified and matured otaku culture produced by the generation before them. The third generation consists of those who were born around 1980 and were junior high school students at the time of Neon Genesis Evangelion.

The book describes the interests of each group to differ slightly, but the passion for comic, anime, and computers reaches across generations. For instance, the first generation's main interest was in science fiction and B-grade movies, those in the third generation had a thorough fascination with mysteries and computer games. The spread of Internet helped the latter group focus their interests on Web sites, illustrations, and computer graphics. The sense of compatibility with Japanese images contained in otaku works has been a focus of Azuma's study. For example, it is said that "the slapstick comedy, in which aliens or strange beings created from legendary motifs, such as ogres, snow-spirits, and benzaiten (Japanese version of the Hindu goddess of fortune) appear dressed in sexually suggestive costumes reveals how otaku fantasy is steeped in Japanese conceits (p. 7). Furthermore, the characters in anime otaku, the settings, stories, as well as themes revolve around those that are typical in Japanese reality. Azuma describes this as otaku culture being connected in various ways to the problems of Japan (Okada, 1996). Otaku works often take Japan as the subject matter, use numerous Japanese expressions, and are consumed in a thoroughly Japanese fashion. The connection between otaku culture and traditional Japanese culture has been pointed out in previous studies as well. For instance, Otsuka (1989) analyzed derivative works by drawing on concepts found in kabuki and old-school "bunraku" puppet theatre where each work adheres to a determined "world" or "idea" (pp. 13-14). Similarly, Okada (1996) asserted that otaku sensibilities are linked to "iki" or the urbanity of Edo culture (pp. 31-32). Perhaps the most famous example comes from contemporary artist Murakami Takashi (2000) who pointed out that "the unique compositions of present-day animators correspond to the "eccentricities" of Edo painters, while the development of figurine makers repeat the history of Buddhist sculptures in Japan" (p. 32). It was in the 1980s that the term "otaku", originally a formal way of saying "you", came to refer to a category of people namely, amateur fans of anime and manga. By 1985, the term otaku-zoku (otaku tribe) was used among manga artists and fans (Goodman, 2012) as a "witty reference to themselves" (p. 13). 


\section{The Social Stigma}

Otaku became a subject of concern in Japan in the early 90's when it faced its first otaku serial killer (Chang, 2000, p. 2):

When police finally caught up with Tsutomu Miyazaki, they found the 27-year-old living in two realities. By day he was a sullen apprentice at local print shop. By night he lived out the fantasies he had internalized from avidly watching his collection of more than 6,000 slasher videos and pornographic manga-Japanese comic books that police found in his room.

Miyazaki was found to have molested and killed four girls. For a society that had been perceived as relatively safe (Chang, 2000, p. 3), this came as a shock. Miyazaki was found to possess the general characteristics of an otaku, described above, most distinguishing of which is shyness. With shyness comes common descriptions for discomfort and inhibition in the presence of others, all of which are taken as signs of psychological maladjustment or arrested development (Pustz, 2008).

Kinsella (2000) identified the "otaku moral panic" ensuing from the Miyazaki case of 1989 as "the sense that this unsociable otaku generation was multiplying and threatening to take over the whole society was strong" (p. 311). The "otaku tribe" quickly assumed the image of isolated deviant (male) youth who shut themselves up in their rooms, engrossed in manga and anime, out-of-touch with everyday social reality. After this, the word "otaku" started to be used as a stigmatizing label for people for people who love anime, manga, and games (Ito, 2012).

\section{The Vicious Cycle}

An attempt to trace the social transformation of a sub-culture, as the otaku, cannot do away without looking into the shifts in social perception of the group, from social misfits with personality disorders to acceptable members of a consumer society. The social stigma that has been cast on otaku individuals in the beginning can be attributed to around roughly three reasons, each one inseparable from the other: First, the weirdness of the otaku individuals in terms of their appearance; secondly, their personality and communication problems; and thirdly, their difficulty to form social connection which gives rise to anti-social behavior, such as crimes apparently resulting from these factors. Each of these categories will be briefly described.

One strange characteristic of otaku individuals is their unkempt and unclean appearance. Since their obsession with their object of interest is all that matters for the otaku; they do not care about their physical appearance. The fact that they follow a fashion different from the ordinary makes them outstanding. This, together with their low interpersonal skills, seems to be a reason why they have been described as "unbalanced specialists" that tend to be avoided (Miyadai, 1994, p. 22).

Besides the uniqueness in the way they dress, otaku people are said to have personality problems which is basically rooted in their inability to communicate. Azusa (2001) wrote "personality problem essentially lies in the fact that otaku find more meaning in relationships with objects, media, and other creations than with people (p. 112). The otaku tribe came to take on the image of isolated young males who shut themselves up in their room engrossed in media (Namba, 2005, p. 139). The reason why otaku do not know how to act appropriately around other people is attributed to their lack of interaction with the real world, as described in Oldenburg (1999, p. 35).

The otaku spend most of their time with their obsession, for example, in front of a television set watching anime. As a result, they get most of their ideas of social interaction by watching how anime characters act. Unfortunately, anime does 
not portray the real world accurately causing these people to act and dress themselves up differently outstanding. Thus, otaku feel misunderstood and stay away from non-otaku. This leads them to watch more anime where they learn some of the behaviors that non-otaku find weird or unappealing. In short, the relationship between otaku and non-otaku could sometimes be described as a vicious cycle.

Spending time alone most of the time and living in an imaginary world watching cartoons or reading comics is interpreted as "a sign of psychological maladjustment or arrested development" (Pustz, 1999, pp. 37-55). Being obsessed with a particular object alone does not explain entirely the strange personality of an otaku individual. In fact, this leads to a deeper and more serious personality problem. Saito (2007) explained that,

The assumption that sexuality is an important factor is useful for an understanding of the otaku personality. Otaku as a personality type that is able to find sexual gratification by means of images of cartoons or comic characters. Otaku behavior is related to fetishism, a symptom that expresses a sexual idea that relates to a symbol. (p. 55)

Strangely enough while the otaku may appear withdrawn from ordinary people, they are sociable with members of their own community. They gravitate around individuals of their own kind where they form a strong tie. They assemble at a common meeting place where they share stories and exchange important information and their individual works. Oldenburg described this behavior as follows (1999, pp. 130-135):

Adult of working otaku individuals have special places where they can get away from their professional and domestic lives. These places are homes away from homes where people can relax. To the otaku, these places are anime or manga stores. In these stores, otaku don't need to feel ashamed of being otaku since everybody in the store likes anime. These stores can sometimes turn into some sort of clubhouse, where people can make friends or talk to the owner. These anime stores are often described as coy especially for the otaku because these are places where they can be themselves with people of their kind. These anime stores are often described as exclusive and perhaps, the exclusiveness of these stores is what otaku look for.

If the otaku stores were accessible to everybody, then otaku would not feel comfortable being there. These stores would not be any different from any other stores.

Because of their unique physical appearance, their inability to communicate, and a very limited interaction with the outside world kept to a minimum, the otaku population has been considered as social outcasts (victims) and as marginalized members of society. On the streets, people used to be afraid of otaku and their fanatical devotion to anime and manga-and other objects of their obsession because such behavior was unfamiliar to them, and regarded otaku as possible cause of problems, sometimes apparently imaginary, and sometimes real.

How are personality problems and inability to communicate and socially interact related to anti-social behavior? Following the moral panic of the Miyazaki case, psychologists jumped onto the bandwagon and the years that ensued saw a proliferation of studies that focus on the otaku individuals as social misfits. Some of the psychological disorders associated with otaku individuals will be mentioned here. In the beginning, otaku individuals were classified into four types: anime and manga otaku, cosplay otaku, game otaku, and figure or doll otaku. These types that first came into the social scene will be briefly discussed here to show how and why otaku traits have been linked to personality disorders and anti-social behavior. First, anime and manga otaku individuals are described as schizotypal while the characters of cosplay otaku are described as histrionic. Furthermore, game otaku individuals are described as anti-social, while the figure and doll otaku are described as obsessive-compulsive individuals (Azusa, 2001). 
Miyadai (1994) described the characteristics of anime and manga otaku as related to schizotypal because of their obsessive interest on objects that are mainly animation and comics. They create their own little fantasy world filled with anime "bishounens" and "rabu-rabu" and this schizotypal tendency hinders them from creating "normal" relationships, thus making them school outcasts and bottom feeders of the social food chain (pp. 24-37). Saito (2000) described the character of cosplay otaku individuals as lively, dramatic, enthusiastic, and flirtatious. These traits are closely associated with histrionic personality disorder (HPD) which is characterized by a pattern of excessive pattern of emotionality and attention-seeking with an excessive need for approval. The third group called game otaku are individuals with obsessive interest in playing video games. Although no actual count has been made, this group seems to be the largest group in Japan (Nakajima, 1991). Why do certain individuals get so attached to games in the imaginary world? In the gaming world, there are no attachments. There are rules but they can be bypassed. One does not have to care about others. It is just the player and the game. Nothing else matters (p. 5). Although no clinical study has pointed the relation between game otaku and personality disorder there is a risk for anti-social personality disorder (ASPD) to develop from obsession with games. ASPD is a pervasive pattern of disregard for, violation of the rights of others. Their traits include failure to confirm to social norms, impulsiveness, irritability or aggression, and lack of remorse, to name a few. "Surely enough, you don't feel remorse when you're shooting down a counter-terrorist. On the contrary, it excites you. The thrill of killing gives you such a high that no other drug can produce" (Zimbardo, 1996, p. 5). The fourth group called figure and doll otaku have obsessive interests in collectibles like posters, accessories, figures, and of course, dolls. These otaku possess a freakish love for control and details (Simmons, 2002). "Everything has to be perfect: from color to texture, and even strokes. They have a constant need to make things absolutely perfect. Preoccupation with orderliness, perfectionism and control make them perfect candidates for people with obsessive-compulsive personality disorder" (p. 75).

The Akihabara Incident in June 2008 continues to relate otaku to problematization (Toivonen \& Imoto, 2013). The serial murderer-a 25-year-old dispatch worker-“was labeled an otaku by much of the press" (p. 73). Azuma (2001) made a social analysis of the 20 years period following the Miyazaki murder case of 1987 up to the Akihabara massacre of July 2007-including the Ikeda School massacre in Osaka on June, 2001. The period is grimly described wherein individuals are loosely connected, with each individual shut off from the world at large (p. 15):

Society has diversified rapidly; every individual has come to express himself in whatever form he likes. Unfortunately, some individuals could not find the route that connects themselves to society, and have resorted to locking themselves up in their own world. These social outcasts are what society has come to label as "otaku.

\section{The Growth From a Niche to a Mass}

The social stigma imposed by social media and research on otaku individuals, as seen above, did not prevent these individuals from growing from a marginalized group to socially accepted members of mainstream society. This section will discuss some of the factors that led to the growth of the group within the local culture.

\section{Deliberate Social Attempts to Protect}

Whereas the 1990s saw the "otaku" as symbols of a fragmented Japanese society, by June 2008, a popular Japanese magazine AERA pronounced the otaku group as gaining their "civil rights" (Noguchi, 2008). How did the change of perception come about? Goodman et al. (2012) identified a couple of factors. First, Okada Toshio, producer off the influential TV anime series Neon Genesis Evangelion, started to promote positive images on 
otaku in his lectures. One of his strategies was to elevate the meaning of otaku in order to re-import an "international concept of otaku in order to frame it at the level of Japanese national identity" (pp. 13-14).

Another influence was Murakami Takashi who started to investigate the nature of Japanese in his works as a painter, and began to represent otaku culture as "Japanese art" overseas. Through Murakami's Art, Japanese anime and manga were popularized in the US and Europe where the concept of otaku was "detached from its original stigmatized meaning within Japan" (2000, p. 15).

Otaku quickly came to be perceived as not only consumers but also creators of Japanese popular culture, and Akihabara, Tokyo's downtown area that had catered for otaku sub-culture since the 1990's, was redeveloped by political leaders and businesses into a 'popular culture showcase'. By 2006, Foreign Minister was calling himself an otaku, indicating how the word has become a national cultural symbol, and hence a political and diplomatic tool.

\section{Diversified Interests and Highly Advanced Consumption}

Besides the social protection given to the otaku group, the growth of "otaku" population in general and the tremendous ramifications of otaku genres, as will be described in this section, can be said to contribute to the change of social attitude and perception towards these individuals. As seen in the discussions earlier, the types of otaku individuals, originally categorized into four groups grew further in types and numbers. The objects of interests, the proliferation of goods in Japan as a consumer society, alongside the passion and obsession of otaku individuals in Japan have diversified so much, so that Spacey (2012) identified 12 different types of otaku currently observed in the country recently, including the four types described previously. The rest of the eight remaining types will be briefly defined below in order to show how the otaku culture has attracted general public interest besides the original fantasy worlds of anime, manga, and games.

The idol \& J-pop otaku (Wota) (Spacey, 2012, p. 1). Wota is a person obsessed with female or male idols, often J-pop idols. For example, the J-pop group AKB48 has a musical theatre in Akihabara where they perform nightly, attended by fans. Wota collect idol magazines and posters and all other goods and collection items. They often seek to meet or photograph their idols in person in concerts.

The train otaku (Tetsudou otaku) (Tsuji, 2012). One of the most archetypical types of otaku to emerge in Japan is the train otaku also called Tetsudou Otaku. Train otaku culture has a long history with roots reaching as far back as pre-World War II Japan. Japan is known for having one of the most developed train system (Tetsudou) in the world. In the earlier period, steam locomotives and scientific models were a media of fantasy. The "train boys" created models with their own hands. "With the advent of advanced consumer society came a shift from a collection of real, concrete objects" (pp. 3-23). At present, the train otaku have a strong attachment to photographing trains and/or riding trains. The objects of interest expanded to collecting and/or wearing train uniforms and collecting model trains.

The robot otaku (Spacey, 2012). Robot research has occupied a large area of Japan's technological investment. Robot otaku are interested in popular culture related to robots, and may also take interest in robot research. "In extreme cases, they are involved in building robots, as a hobby (p. 2).

The pasocon (Computer) otaku (Morikawa, 2012). In addition to these diversified groups of otaku individual, the computer otaku, also called Pasocon Otaku, has been identified as one large group of computer fanatics. The development of Akihabara and the remaking of stores was the birthplace of personal computers, alongside the advent of Japan's highly advanced consumer society. Pasocon Otaku is obsessed with computer technology. They study hardware and software specifications of computers in extreme detail. They enjoy 
exchanging ideas on the latest devices and spend large amounts of time configuring and customizing software (pp. 141-144).

The wapanese otaku (Spacey, 2012). The word wapanese comes from the English "Want to be Japanese". They are non-Japanese people who have an obsessive interest in multiple aspects of Japanese culture. They may develop an incredibly positive view of Japan that is somewhat unrealistic. Some of them become thoroughly skilled in many aspects of Japanese culture, such as Japanese language and/or martial arts.

The female history otaku (Reki-jo) (Miyadai, 1994). Another recently expanding group of otaku has been identified for their obsession with various aspects of history. They are called female history otaku, or female history buffs called Reki-jo in Japanese. They are extremely interested in pre-industrial Japanese history. They view this period as an ideal age of innocence and adventure. Reki-jo often gather together to dress in period costumes. They may adapt or revive the speech and mannerisms of old Japan or the age of their obsession.

The voice actress otaku (Seiyuu otaku) (Spacey, 2012). Still another recent group whose rise coincided with Japan's technology consumption is the voice actress otaku called Seiyuu otaku. This group is one of the many sub-types of anime otaku. They are obsessed with the voice actors and actresses of Anime characters and Anime productions. Due to the country's long history of anime, voice acting is taken seriously in Japan. Gamers and anime fans pay close attention into who are bringing the characters to life. The voice otaku collect recordings of their interests and/or imitate these using their own voice recordings. The ease of recoding technology at home, at school, and society at large has attracted many young individuals to this group. Besides, due to the country's long history of anime, voice acting is taken seriously in Japan. Gamers and anime fans pay close attention into who is bringing the characters to life.

The military otaku (Gunji ota) (Tsujii, 2012). Gunji is the Japanese word for military and ota is shorted form of otaku. Gunji Ota is described as being obsessed with military items and hardware, and in wearing military uniforms. They also have a keen interest in collecting military figures, and even war stories that come in manga form. Back in the early 80 's and 90's, military modeling figures were largely produced. Complexity ranges from simple assembly and painting of a model kit out of the box to a complete building of vehicle, aircraft, or ship from materials, such as wood, plastic, or metal.

A common element is present in the various definitions that have been posted about otaku persons and the otaku world. Otaku is people who are obsessed with a hobby to the extent that it becomes a major part of their identity. With the diversification of objects of interest, as seen above however, the definition has come to imply that any person can be an otaku about practically any hobby or interest. The negative connotations of the word otaku, much like the English word "nerd" that implies socially awkwardness have disappeared and (Ito et al., 2012).

By 2007, otaku market in Japan was estimated to be worth 186.7 billion yen a year and otaku were being discussed as symbols of Japan's cultural power (Goodman et al., 2012). The publication of Okada's book (2008) officially proclaimed that "the otaku are already dead" (p. 25). As a consequence, the Japanese public have changed perception and have come to recognize some positive influences of the "otaku" group on Japanese society (Eng, 2001). Japanese society has now become more aware that otaku-ish fanaticism does not necessarily imply antisocial and violent behavior.

\section{An Emerging Set of Mainstream Youth Problems}

The pathological view of otaku no longer exists, in part because of the emergence in the turn of 2000 of a 
new form of youth problem, the hikikomori (Goodman, 2012). A longitudinal study by Kikuchi (2008) suggested that the negative connotations on otaku have significantly disappeared. Otaku nowadays not only means just being a fan of cartoons and comics but generally characterizes people who have curious hobbies and indulge in intensive preoccupation with an object of interest (Yonezawa, 1991). This preoccupation does not necessarily mean an obsession, as in the past. You can be a Star Wars otaku, a Hello Kitty otaku, a horror movie otaku, and a video game otaku heck; you could even be a fishing otaku. Each one of us can practically become an otaku. In the beginning, the word evoked images of sociopathic shut-ins out-of-touch with reality. Recently, however, the word otaku suggests a postmodern sensibility expressed through knowledge of pop and cyber culture and technological fluency in a networked world.

Toivonen and Imoto's (2013) study on Japanese youth showed the rise of other anti-social behavior problems that created a stir, such as those of the extremely withdrawn hikikomori youth. The Japanese public became aware that "deeper social problems like the pressure to fit, cutthroat academics, bullying and other problems are more likely to case real psychological damage in youth" (pp. 74-75). Instead of stereotyping the otaku as being sociopathic and blaming anime and manga for creating monsters, the Japanese public has been forced to acknowledge that problems among youth are complex and there are no simple solutions. Instead of looking towards the otaku sub-culture, Japanese society was forced to take a closer look at itself (McLuhan, 2006).

\section{Global Expansion of Otaku Culture}

The impact of otaku culture now reaches far beyond Japan (Guo, 2008). Worldwide acceptance of Japanese manga culture can be seen in various forms most popular of which include its worldwide publications in different languages and adaptations of the original Japanese "otaku" films and their characters, as well as otaku collectibles. This section looks at the cultural ramifications of Japanese otaku sub-culture from the following perspectives: the worldwide spread of Internet cafés, the construction of Comic Markets, the expansion of otaku specialty stores, the annual gatherings called anime conventions in different countries, and other forms of cross-cultural pollinations. While the origins of otaku culture can be found in postwar Japanese experiences and imaginations, its international circulation grew in torrents from the last decades of the 20th century to the present (Ito et al., 2012). Accelerated in part by the international expansion of fan activities and emerging forms of digital and network communication, otaku culture found its way in the countess gatherings around the world while retaining a distinct Japanese cultural identity (Shirky, 2006).

\section{Japanese Animation and Otaku Culture in US and Asia}

In the past, animation was considered "candy for kids" in most countries. It was not accepted by adults, particularly in the US. But Japan has replaced the US as the world's largest exporter of animation (Wu, 2008). Azuma (2009) however reminded us that whether it is anime, special effects, science fiction, or computer games of the magazine culture, otaku culture in reality originated as a sub-culture imported from the USA after World War II. The Japanese otaku culture has had its champions in the US, and is one of adaptation, of how to "domesticate" American culture within Japan. What started as a small group of American anime enthusiasts in the 1970s has grown to a massive and diverse sub-culture (Eng, 2012). Japan has been exporting approximately 4.35 billion dollars of ACG (animation, comic, and game) to the country, and everyone concerned with the development asked "How could Japan do that?" 


\section{The Otaku Conventions}

Anime conventions are large fan gatherings that have multiple programs and keep fans occupied for two to four days. Although otaku culture became more visible to the American mainstream through several different avenues (Eng, 2012), the ultimate events for anime culture, however, are the anime conventions. The annual conventions are created as a space for communication, creation process, and simply enjoyment. American fans started the first Otakon, a Convention of Otaku Generation in 1990s (p. 159). By 2008, the first East Coast largest annual gathering of 25,000 anime fans has brought thousands of people from multiple states in the US, with up to 40,000 attendees on the West Coast (p. 173). Through these gatherings, Japanese artists brought the otaku aesthetic sensibilities in the world of art and fashion to international audience. International collectors of character figurines-influenced by Murakami's art work at that time-were on display and for sale. In Europe, the first otaku assembly was started in Finland. With a growing network of mutual support for otaku individuals in the country, Finland holds different anime and manga related conventions called animecon since 1991 (Isida, 2010). Currently, Finland looks to be the representative country in Europe to "adopt not only the manga and animation culture of Japan, but the other aspects of otaku culture as well” (p. 28). Similarly, Europe's largest-in scope-Japanese entertainment festival is held at the Paris-Nord Villeprinte Exhibition Center. The expo included a large exhibition of manga, game, and music events. Visitors of the previous year were reported to total 210,000, a record-breaking attendance. Paris' passion for Otaku has been consistently on the rise. Cosplay, as a genre, has gained tremendous popularity in the conventions, with many people cosplaying characters from popular Japanese works. Besides young otaku, visitors spanned a wide range.

Japanese otaku culture has spread similarly in Asia through the otaku conventions. In Singapore, for example, the Anime Festival Asia (AFA) is held yearly for three days. Attendance participation in the last gathering reached 85,000 , well exceeding that of the previous year's event. Otaku conventions have become popular in Asian countries as well. Malaysia, for example, is not without the annual otaku entertainment. It holds its yearly otaku convention in the most lavish way in the most prestigious convention centers of the country where attendance is described as epic. Hongkong likewise holds its annual Japanese Anime Exposition, the last one being on March 15-18, 2013 at the Hong Kong Convention \& Exhibition Centre. For otaku who cosplay, anime conventions are a place where they can show their sills and expertise. As in the otaku assemblies in Europe, the Cosplayers' laboratory called Cos Lab has been an essential part of any on-going and regular otaku entertainment activities in the conventions in Asia. Otaku conventions or anime festivals, as they are called in Malaysia, are held annually. Unlike in Japanese otaku conventions where amateurs can display and sell their works however, in otaku conventions abroad companies bring in their products, such as books and figures to sell. Thus otaku culture found its way into the international scene through expansion of fan activities in countless gatherings worldwide while retaining a distinct Japanese cultural identity (Shirky, 2006).

\section{The Specialty Stores}

The proliferation of specialty stores is a proof of the expansion of influence and power of Japanese otaku in general, and anime in particular, in its neighboring Asian countries and in the West. Specialty, stores are shops that feature and sell manga and anime-related goods and practically everything related to otaku interests and activities (Morikawa, 2012). Certainly, tour companies emerged to meet the increasing demand of American otaku who wishes to visit Japan to shop for otaku items in specialty stores. These companies, often 
working in conjunction with Japan's tourist industry, offer otaku-oriented tours to popular areas, like Akihabara, anime and manga-related museums, and anime studios. The tours usually end with a visit to the specialty stores. This kind of stores is also popular overseas. For instance, in Singapore, these stores are called otaku house and are very popular stores frequented by otaku fans. They sell a huge collection of curious toys and gifts. The stores are characterized by friendly customer service by salesgirls in manga costumes. In Hongkong, the expansion of otaku culture brought in a proliferation of otaku goods stores in the country. Besides, selling special otaku related goods, the manga stores are a characteristic architecture of otaku taste found worldwide. Similar to specialty stores, manga stores sell not only otaku magazines; they are specialty stores that sell comics, videos, DCs and DVDs, game cards, models, costumes, and figurines-everything and anything that caters to the otaku interest in multiple media forms.

While otaku goods found their way in specialty stores in the US, Europe, and Asia, a distinct kind of store that sells particular otaku items has come to public attention. The name is Cos Lab, a short cut for Cosplay Costume Laboratory. A Cos Lab is a place where not only Europe and Asia's most popular cosplayers are introduced. It is a special kind of store where collections of some of their finest works are displayed. In Hongkong, grand and elaborate display of cosplay is a favorite entertainment based on Japanese characters, with most popular characters being Sailor Moon/Sailor Chibi Moon \& Eternal Sailor Moon. The group spends lavish amounts in the said event inviting many famous Japanese voice anime actors and actresses, such as, "Gundam", "Slam Dunk", and so on.

\section{The Internet Cafés}

The availability of online media through Internet Cafés helped disseminate otaku news and activities and contribute largely to the expansion otaku culture in Asia and in the West. In Europe, the first manga café opened in Finland in 2009. It serves both the function of a coffee shop and a library for comic books. It originally started with a small only 19 seats coffee shop, with the interior decorated with popular manga characters. It spread to other areas of the country alongside the popularization of anime and manga in Finland (Ishida, 2010). Similarly, Internet Cafés are abundant in Asia. In Malaysia, for example, Internet Cafés were popularized as Cyber Café. In Singapore, there are different types of Internet Cafés ranging from low to high quality and from cheap to expensive ones. Most Internet Cafés serve for 24 hours. They can be found either as independent units-or shops, but most are found in shopping malls. Internet Cafés are seen in many places in Hongkong and serve the needs mostly of tourists. Aside from Internet browsing, Cyber Cafés offer other services like gaming and burning photos into CD or DVD in an elegant environment and state-of-the-art system. Cyber Café online indicates that there are currently 4,208 Internet Cafés in 141 countries worldwide.

\section{The Comic Markets}

Besides the otaku conventions, the comic market is another large otaku event that fanned the growth of otaku culture overseas. First held in Tokyo in 1975, a comic market is a space where people with passion for manga and anime flock to enjoy (Tamagawa, 2007). Called comiket for short, it runs by a voluntary committee and is participated in by several comic publishers who produce works in lots of genres to sell in such gatherings. It also provides general manga and anime fanatics to sell self-published work. Although anime fans encounter otaku as a cultural concept even at mainstream book retail stores that sell anime and manga-related merchandise, the comic market is a unique place. The first Comiket in Japan had only about an estimated 600 attendees from 30 participating groups (p. 11) but has gained popularity since them. 
Outside Japan comic markets continue to be one of the largest otaku activities in the world where Japanese works are sold. In Finland, for example, 95 percent of the comics are manga from Japan, while the rest are from US and France. Translated publications of Japanese manga into several languages are available. In Hong Kong, for example, there are gatherings similar to the Comic markets called Comic World in Hongkong (CWHK). It continues to attract both male and female fans. The spread of his type of comic related dojinshi conventions has spread to western word, like the Anime Expo (held annually in the US) and Japan Expo (held in Paris). In Malaysia, otaku fans gather to the Comic Fiesta of CF for short. The gathering focuses on animation, comics, and games (ACG) which is similar to the comic market in Japan. The aim is to celebrate all aspects of art and creativity. It is usually held in December and in various locations, the latest of which was at Kuala Lumpur Convention Center, attracting approximately 35,000 visitors. Tamagawa described the comic market as a massive market that is "an expression of otaku space for self-expression and distribution" (2007, p. 123). In Finland, an event similar to the comic market is held. In Finland, an event similar to the comic market is held. For instance, a comic book fair was held in Tampere, the purpose of which is to introduce Japanese comics and cartoons in general. It started as a one-day event in 2007 attended by 3,000 people (Ishida, 2010) and in 2008, the event was extended for three days, with an expanded program content of "cosplay contest, manga panel discussions, anime screenings, and even adult Japanese manga discussion" (p. 30).

In the past, stereotypes of the otaku in Japan picture them as socially isolated and hardly capable of inter-personal interaction, as seen in the first section of this paper. But the otaku individuals defied the original stereotype and found their way within the local culture through their peer-peer activities, as seen in the next section. Through these common participatory and communal activities, the otaku culture continued is transnational expansion beyond Japan. These activities occur in a multitude of activities, such as the otaku conventions, comic markets, and otaku specialty shops. Other factors, such as technology and the Internet have been put forth as contributing to the transformation of the otaku culture from a niche to a mass. Guo (2008) described of these factors as follow (pp. 9-12):

Japanese animation distribution allows dubbing into the language of the country, and adding subtitles, and allows local editing of original character references to fit the cultural contexts. DVD replaced VHS, and Internet allowed the possibility to include multiple language tracks.

The most profound change affecting anime otaku networks has been the growth and development of the Internet (Eng, 2012). "It made possible the unprecedented number of people sharing common interest to interact with each other" (pp. 100-102). This section focused on the interpersonal networks used by otaku individuals through formal and informal associations and face-to-face strategies of engagement.

\section{Conclusion}

This paper has traced the transformation of otaku culture from a highly stigmatized group to a useful consumer sub-culture contributing to the economy of the country. This can be attributed to factors, such as diversification of interests and the proliferation of consumer goods in Japan (Spacey, 2012) alongside society's deliberate effort to protect the group which Ito et al. described as "irreducible diversity" (2012, pp. 275-280). In addition, an emerging set of mainstream youth problem (Toivonen \& Omoto, 2012) created a "new set of moral panic) (p. 12) that needed more urgent attention that otaku individuals. The growth of otaku sub-culture inside the Japanese society showed a pattern of resistance before acceptance and accommodation. In the beginning, 
the physical and psychological characteristics of otaku individuals as well as their anti-social behavior, discussed in earlier sections, gave people reasons to believe in them. Media coverage of crime accidents and social research helped strengthen public fear. With their economic contribution to society caused by the tremendous increase in size and interests, the public has become aware that otakish fanaticism does not necessarily imply antisocial and violent behavior.

Besides its transformation within the local culture, the otaku group has taken the world. The last section of this paper has examined the extent otaku activities spread beyond local boundaries by focusing on the interpersonal networks used by the otaku groups. These interpersonal networks found way in their formal and informal association and face-to-face strategies of engagement. Four factors were found to have facilitated the cultural ramifications of Japanese otaku sub-culture overseas: the worldwide spread of Internet Cafés, the proliferation of comic markets, the expansion of otaku specialty stores, and the annual gatherings called anime conventions. Its growth outside Japan was fanned by the familiar process of culture exchange between Japan and the rest of the world, and the key to its strong visibility lies in the unique conditions of a networked and digital culture.

\section{References}

Azuma, H. (2001). Doubutsukasuru post modern. Tokyo: Kodansha.

Azuma, H. (2009). Japan's database animals. Minneapolis: University of Minnesota Press.

Azuma, H. (2012). Database animals. In M. Ito, D. Okabe, \& I. Tsuji (Eds.), Fandom unbound (pp. 30-67). New Haven, Connecticut: Yale University Press.

Chang, T. (2000). The strange world of the otaku: Language, thought \& culture. Mississippi: University Press of Mississippi.

Chen, C. W. (2004). Globalization of Japanese animation and fandom culture. Taiwan: Tanshan.

Eng, L. (2001). The current status of otaku and Japan's latest youth crisis. Retrieved June 15, 2014, from ttp://cjas.org/ leng/hihiko.htm

Eng, L. (2012). Strategies of engagement. In M. Ito, D. Okabe, \& I. Tsuji (Eds.), Fandom unbound (pp. 96-104). New Haven, Connecticut: Yale University Press.

Goodman, R. (2012). A sociology of Japanese youth. London: Routledge.

Goodman, R., Imoto, Y., \& Toivonen, T. (2012). A sociology of experience. In T. Greenfield \& P. Robbins (Eds.), Greenfield on educational administration (pp. 53-74). London: Routledge.

Guo, Y. X. (2008). Global influence of Japanese animation. Georgia, United States: Southern Polytechnic State University.

Hashimoto, M. (2007). Visual Kei otaku identity. Intercultural Communication Studies, 16(1), 43-47.

Hikari C. (2012). A study of what otaku is outside Japan. Retrieved July 15, 2014, from http://www.ani-culture.net/2012/02/a-study-of-what-otaku-is-outside-of-japan/

Ishida, Y. (2010). Finnish fandom of Japanese popular culture (Master's thesis, University of Jyvaskyla).

Ito, M. (2012). Anime and manga fandom as networked culture. In M. Ito, D. Okabe, \& I. Tsuji (Eds.), Fandom unbound (pp. 158-178). New Haven, Connecticut: Yale University Press.

Ito, M., Okabe, D., \& Tsuji, I. (2012). Fandom unbound: Otaku culture in a connected world. New Haven, Connecticut: Yale University Press.

Kikuchi, S. (2008). The Transformation and the diffusion of "Otaku" Stereotypes and the Establishment of "Akihabara" as a Place-brand [Original title: "Otaku” sutereotaipu no hensen to Akihabara-burando]. Shinshu University.

Kinsella, S. (1998). Japanese sub-culture in the 1990s: Otaku and the amateur manga movement. The Journal of Japanese Studies, 24(2), 289-316.

Kinsella, S. (2000). Adult manga: Culture and power in contemporary Japanese society. Honolulu, USA: University of Hawaii Press.

McLuhan, M. (2006). The current state of otaku and Japan's youth crisis. Retrieved May 12, 2015, from http://www.cjas.org/ leng/hikiko.htm

Meuser, J. (2013). Singapore heats up! Retrieved March 5, 2014, from http://otakumode.com/news/528432f79d09d76e4f00004b/Singapore-Heats-Up! 
Miyadai, S. (1994). Seifuku shojotachi no sentaku (The choice of the school uniform girls). Tokyo: Kodansha.

Morikawa, K. (2012). Otaku and the city. In M. Ito, D. Okabe, \& I. Tsuji (Eds.), Fandom unbound (pp. 141-147). Yale University Press.

Nakajima, A. (1991). Communication fushizen shokogun (Dysfunctional communication syndrome). Tokyo: Chikuma Shobō.

Nakajima, A. (1991). Communication fushizen shokogun (Dysfunctional communication syndrome). Tokyo: Chikuma Shobō.

Namba, K. (2005). Postwar youth and sub-cultures: The otaku tribe and the Shibuya types. Kansai Gakuin Sociology Department Studies, 99, 131-153.

Noguchi, I. (2008). Transcending labels and panic: The logic of Japanese youth. Contemporary Japan, 25(1), 61-86.

Okada, T. (1996). An introduction to otaku studies. Tokyo: Ota Shuppan.

Okada, T. (2008). Otaku wa sudeni shindeiru (Otaku Is Dead). Tokyo: Shinchosa.

Oldenburg, R. (1999). The great good place. New York: Marlowe \& Co.

Otsuka, E. (1989). Theory of narrative consumption. Tokyo: Shinyousha.

Pustz, M. (1999). Comic book culture: Fan boys and true believers. Mississippi: University Press of Mississippi.

Saito, K. (2007). Visual kei-otaku identity. Intercultural Communication Studies, 16(1), 51-57.

Saito, T. (2000). Sento bishojo shishinbunseki (The psychoanalysis of fighting girls). Tokyo, Ota Shuppan.

Salazar, G. (2014). Four types of otaku: A psychological analysis. Retrieved from http://www.gamertotoy.com

Shirky, C. (2006). Creative surplus: Creativity and generosity in a connected age. New York: Penguin Press.

Simmons, R. (2002). The odd girl out: The hidden culture of aggression in girls. New York: Harcourt Brace International.

Spacey, J. (2012). Twelve types of otaku: Japan talk. Retrieved March 5, 2014, from http://www.japan-talk.com/jt/new/12-types-of-otaku

Takashi, M. (2000). Are all anime fans fanatics? Retrieved May 12, 2015, from http://www.jca-online.com/murakami.html

Tamagawa, H. (2007). Sorezore no fan kenkyu: I am a fan. Tokyo: Fujinsha.

Taussig, M. (1993). Mimesis and alterity. London: Routledge.

Toivonen, T., \& Imoto, Y. (2013). Transcending labels and panics: The logic of Japanese youth problems. Contemporary Japan, $25(1), 61-86$.

Tsuji, I. (2012). Why study train otaku? In M. Ito, D. Okabe, \& I. Tsuji (Eds.), Fandom unbound (pp. 3-26). New Haven, Connecticut: Yale University Press.

Wu, W. M. (2008). The impact of Japanese manga on pop culture. Twenty First Century, 72(2), 105.

Yonezawa, Y. (1991). The world of collection b-class American memorabilia. Tokyo. Shobunsha.

Zimbardo, P. (1996). Shyness: What it is, what to do about it. Reading, MA: Adison-Wesley Publishers. 